\title{
Action of Aqueous Extracts of Phyllanthus niruri L. (Euphorbiaceae) leaves on Meristematic Root Cells of Allium cepa $\mathrm{L}$.
}

\author{
ERASMOVLANE S.B. NEVES ${ }^{1}$, PAULO MICHEL PINHEIRO FERREIRA ${ }^{2}$, \\ LEONARDO H.G.M. LIMA ${ }^{1}$ and ANA PAULA PERON ${ }^{1}$ \\ ${ }^{1}$ Universidade Federal do Piauí (UFPI), Núcleo de Pesquisa Aplicada à Saúde e ao Meio-Ambiente (NUPBSAM), \\ Laboratório de Citogenética Vegetal e Animal, Campus Senador Helvídio Nunes de Barros (CSHNB), \\ Rua Cícero Duarte, 940, Bairro Junco, 64600-000 Picos, PI, Brasil \\ ${ }^{2}$ Programa de Pós-Graduação em Ciências Farmacêuticas, Universidade Federal do Piauí, \\ Centro de Ciências da Saúde, Departamento de Biofísica e Fisiologia, Campus Ministro Petrônio Portela, \\ Avenida Universitária, lado ímpar, Ininga, 64049-550 Teresina, PI, Brasil \\ Manuscript received on April 29, 2013; accepted for publication on July 17, 2013
}

\begin{abstract}
This study aimed to evaluate the effects of aqueous extracts of dried Phyllanthus niruri L. (stonebreaker) leaves on Allium cepa $\mathrm{L}$. root meristem cells at four concentrations, 0.02 (usual concentration), 0.04, 0.06 and $0.08 \mathrm{mg} / \mathrm{mL}$ and exposure times of 24 and 48 hours. For each concentration we used a group of five onion bulbs that were first embedded in distilled water and then transferred to their respective concentrations. The radicles were collected and fixed in acetic acid (3:1) for 24 hours. The slides were prepared by the crushing technique and stained with $2 \%$ acetic orcein. Cells were analyzed throughout the cell cycle, totaling 5000 for each control and exposure time. The calculated mitotic indices were subjected to the Chi-squared statistical analysis $(p<0.05)$. From the results obtained it was observed that all four concentrations tested had significant antiproliferative effect on the cell cycle of this test system. We also found the presence of cellular aberrations such as colchicined metaphases, anaphasic and telophasic bridges, and micronuclei in the two exposure times for all concentrations evaluated. Therefore, under the conditions studied the concentrations of aqueous extracts of leaves of $P$. niruri showed to be cytotoxic and genotoxic.
\end{abstract}

Key words: medicinal plant, stonebreaker, cell division, cellular aberrations, Allium cepa.

\section{INTRODUCTION}

Currently, about $70 \%$ of the world population uses medicinal plants in primary health care (Frescura et al. 2012). However, many of them have not been sufficiently studied for their potential toxic effects at the cellular level (Bagatini et al. 2007, Meyer et al. 2011). These studies are of great importance for contributing towards standardizing quantities

Correspondence to: Ana Paula Peron

E-mail: anpapegenpes@hotmail.com for safe and effective use of these plants by the population (Asare et al. 2012).

Phyllanthus niruri, a species belonging to the family Euphorbiaceae, subfamily Phyllanthoideae, originated in India and is widely distributed in the Americas. This medicinal plant, popularly known in Brazil as stonebreaker, is classified as herbaceous, measuring on average $60 \mathrm{~cm}$ tall, with horizontally ramified stem. Its flowers, yellowgreen, are minutel, dioecious and inserted in the 
leaf axils (Moreira et al. 2013). Its phytochemical constituents have been well established, particularly lignans, tannins and flavonoids, the latter two being present in high concentrations in the leaves (Devi et al. 2005, Asare et al. 2012).

Aqueous extracts obtained by infusion of stonebreaker dried leaves are widely used in popular medicine for the removal of calcium oxalate kidney stones (Álvarez et al. 2009, Nascimento-Barros and Albuquerque 2012), as an eupeptic (Asare et al. 2012), for liver disorders (Murugaiyah and Chan 2009), in alleviating jaundice and in fighting bladder and bowel infections (Abdulla et al. 2010). However, there is a lack of studies in the literature on its toxic effects at the cellular level.

Bioassays with plants are considered appropriate for monitoring of toxic effects of chemical compounds (USEPA) (Grant 1999, Iganci et al. 2006, Herrero et al. 2012). Allium cepa (onion) is an efficient bioindicator of the cytotoxicity of aqueous extracts of medicinal plants (Fachinetto et al. 2007, Sabini et al. 2011). This is due to its kinetic properties of proliferation and because it processes large chromosomes in reduced number $(2 n=16)$, which facilitates their analysis (Matsumoto et al. 2006, Caritá and Marin-Morales 2008, Herrero et al. 2012). This test system is also effective in the evaluation of mutagenicity of aqueous extracts of plants with medicinal properties since it enables the observation of abnormalities of the mitotic cycle, such as colchicined metaphases, anaphasic and telophasic bridges, and interphase anomalies, such as micronuclei and binucleate cells (Leme and Marin-Morales 2008, Sabini et al. 2011).

Thus, due to the widespread use of $P$. niruri by the population, and the need for further studies on the action of this plant at a cellular level, and also considering that the $A$. cepa system is suitable for assessment of cytotoxicity and mutagenicity of aqueous extracts of medicinal plants, this study aimed to evaluate the effect of different concentrations of aqueous extracts of dried stonebreaker leaves, obtained by popular use, on $A$. cepa meristematic root cells in two exposure times.

\section{MATERIALS AND METHODS}

This work was developed on the Senador Helvídio Nunes de Barros Campus of the Universidade Federal do Piauí (UFPI), municipality of Picos, state of Piauí.

\section{PLANT COLLECTION}

Samples of $P$. niruri were collected in a medicinal nursery local in the city of Teresina, state of Piauí, in May of 2012 and identified by Prof Ms Maria do Socorro Meireles de Deus, who holds a master in botany and is a professor at UFPI. The leaves of these samples were then stored under environmental conditions for 6 months. Soon after identification, a control sample of this species was taken to the Graziela Barroso Herbarium of UFPI.

\section{PREPARATION OF INFUSIONS}

Dry stonebreaker leaves were placed in boiling water where they remained in infusion for 10 minutes. Subsequently, the aqueous extracts were filtered and cooled to room temperature. Four concentrations were established, $0.02 ; 0.04 ; 0.06$ and $0.08 \mathrm{mg} / \mathrm{mL}$, of which $0.02 \mathrm{mg} / \mathrm{mL}$ is considered the most common and recommended by the Center for Drug Information Base of Medicinal and Toxic Plants (CIMPLAMT 2012).

\section{OBtAINING MERISTEMATIC CELls FOR CYTOGENETIC} ANALYSIS

The bulbs of Allium cepa, acquired in the produce market in the city of Picos - Piauí, were placed to root in flasks with distilled water, at room temperature $\left( \pm 25^{\circ} \mathrm{C}\right)$, constantly aerated and with a period of twelve hours of light and twelve hours of darkness, until roots with about $1.0 \mathrm{~cm}$ of length were obtained. For analysis of each concentration, an experimental group was stipulated with five bulbs, according to the protocol described by Fiskesjo (1994). 
Before putting the roots in contact with their respective concentrations, some roots were collected and fixed to serve as control (CO) of the bulb itself. Soon afterwards, the remaining roots were placed in their respective concentrations, for 24 hours, this procedure denominated as 24-hour exposure time (ET 24h).

After this time some roots were removed and fixed. Afterwards, the remaining roots from each bulb were returned to their respective concentrations where they remained for 24 hours, which we called 48-hour exposure time (48h ET). After this period, roots were again collected and fixed. Exposure times of 24 and $48 \mathrm{~h}$ were chosen in order to evaluate the effect of the concentrations studied in more than one cell cycle.

The fixing of the roots occurred in Carnoy 3:1 (ethanol: acetic acid) at room temperature for 24 hours. For each root collection, an average of three roots per onion bulb were removed.

Preparation And Reading of the Slides, AND Data

ANALYSIS

The slides, three per bulb on average, were made following the protocol proposed by Guerra and
Souza (2002). Each slide was stained with two drops of 2\% acetic orcein (Fachinetto and Tedesco 2009) and examined under an optical microscope at 40X. For each bulb 1,000 cells were analyzed, totaling 5000 cells for each control and concentration. During the analysis we observed cells in interphase, prophase, metaphase, anaphase and telophase. We calculated the number of cells in interphase and under division for each control and exposure time and determined and mitotic index.

We also evaluated the presence of cellular aberrations such as mitotic cycle anomalies (colchicined metaphases, anaphasic and telophasic bridges) interphasic anomalies (micronucleated and binucleated cells). For this evaluation 1,000 cells were analyzed for each control and exposure time.

The statistical analysis of all the data was conducted through the Chi-square $\left(\chi^{2}\right)$, with a level of probability $<0.05$, through the statistical software BioEstat 3.0 (Ayres 2007).

\section{RESULTS AND DISCUSSION}

Table I presents the number of cells in interphase and at different stages of cell division, and the mitotic

TABLE I

Cell cycle analyzes of Allium cepa root tips treated with the infusion of Phyllanthus niruri leaves at concentrations of $0.02,0.04,0.06$ and $0.08 \mathrm{mg} / \mathrm{mL}$ after $24 \mathrm{~h}$ and $48 \mathrm{~h}$. Analysis of 5,000 cells per group.

\begin{tabular}{|c|c|c|c|c|c|c|c|c|}
\hline Dried leaves/ water & $\begin{array}{c}\text { Exposure } \\
\text { time }\end{array}$ & Cells in interphase & $\mathbf{P}$ & $\mathbf{M}$ & $\mathbf{A}$ & $\mathbf{T}$ & $\begin{array}{c}\text { Dividing } \\
\text { cells }\end{array}$ & $\begin{array}{c}\text { Mitotic Index } \\
(\%)\end{array}$ \\
\hline \multirow{3}{*}{$0.02 \mathrm{mg} / \mathrm{mL}$} & $\mathrm{C}$ & 4200 & 412 & 121 & 89 & 178 & 800 & $16.0^{\mathrm{a}}$ \\
\hline & ET 24h & 4413 & 354 & 73 & 72 & 88 & 587 & $11.7^{\mathrm{a}}$ \\
\hline & ET $48 \mathrm{~h}$ & 4530 & 317 & 33 & 56 & 64 & 470 & $9.4^{\mathrm{a}, \mathrm{b}}$ \\
\hline \multirow{3}{*}{$0.04 \mathrm{mg} / \mathrm{mL}$} & $\mathrm{C}$ & 3878 & 580 & 178 & 149 & 215 & 1122 & $22.4^{\mathrm{a}}$ \\
\hline & ET $24 \mathrm{~h}$ & 4440 & 320 & 26 & 56 & 114 & 560 & $11.5^{\mathrm{b}}$ \\
\hline & ET $48 \mathrm{~h}$ & 4484 & 320 & 96 & 54 & 90 & 516 & $10.5^{\mathrm{b}}$ \\
\hline \multirow{3}{*}{$0.06 \mathrm{mg} / \mathrm{mL}$} & $\mathrm{C}$ & 4237 & 322 & 169 & 112 & 160 & 763 & $15.3^{\mathrm{a}}$ \\
\hline & ET $24 h$ & 4474 & 219 & 103 & 96 & 108 & 526 & $10.5^{\mathrm{a}, \mathrm{b}}$ \\
\hline & ET $48 \mathrm{~h}$ & 4641 & 170 & 66 & 52 & 71 & 358 & $7.2^{\mathrm{b}}$ \\
\hline \multirow{3}{*}{$0.08 \mathrm{~g} / \mathrm{mL}$} & $\mathrm{C}$ & 4120 & 430 & 124 & 108 & 218 & 880 & $18.4^{\mathrm{a}}$ \\
\hline & ET $24 \mathrm{~h}$ & 4151 & 455 & 120 & 78 & 196 & 849 & $17.2^{\mathrm{a}}$ \\
\hline & ET $48 \mathrm{~h}$ & 4439 & 268 & 90 & 88 & 115 & 561 & $11.5^{\mathrm{b}}$ \\
\hline
\end{tabular}

C - Control; ET - Exposure time, h - hour, d - day.

Means followed by the same letter do not differ significantly at the level of 0.05 by the $\chi^{2}$ test. 
index values obtained from root meristem cells of $A$. cepa treated with water and with different concentrations of $P$. niruri under exposure times of 24 and 48 hours.

The results obtained showed that all four tested concentrations of $P$. niruri significantly inhibited MI of meristematic root cells of $A$. cepa under the two ET when compared to the MI of their respective controls. As can be seen, at all concentrations, inhibition of cell division is maintained with the increase of ET. However, when comparing the MI between the ET of a same concentration, we found that they were not statistically significant.
Table II presents the number of colchicined metaphases, bridges in anaphase and telophase, micronucleated cells, and total cellular aberrations present in the root meristem cells of $A$. cepa with water and treated with different concentrations of P. niruri in exposure times of 24 and 48 hours.

In both ET evaluated for the four concentrations, the presence of colchicined metaphases, anaphase bridges, telophase bridges and micronuclei were verified. All concentrations induced a number of cellular aberrations that differed significantly from their respective $\mathrm{CO}$, but did not differ among themselves.

TABLE II

Number of cells with colchined metaphases, bridges in anaphase and telophase and micronucleated cells, and total of aberrant cells treated with the infusion of Phyllanthus niruri leaves at concentrations of $0.02,0.04,0.06$ and $0.08 \mathrm{mg} / \mathrm{mL}$ after $24 \mathrm{~h}, 48 \mathrm{~h}$ and 7 days of exposure.

\begin{tabular}{|c|c|c|c|c|c|c|}
\hline $\begin{array}{l}\text { Dried leaves/ } \\
\text { water }\end{array}$ & Exposure Time & $\begin{array}{l}\text { Number } \\
\text { of cells } \\
\text { analyzed }\end{array}$ & $\begin{array}{l}\text { Colchicined } \\
\text { metaphases }\end{array}$ & $\begin{array}{c}\text { Anaphase } \\
\text { and telophase } \\
\text { bridges }\end{array}$ & $\begin{array}{l}\text { Micronucleated } \\
\text { cells }\end{array}$ & Aberrant cells \\
\hline \multirow{3}{*}{$0.02 \mathrm{mg} / \mathrm{mL}$} & $\mathrm{C}$ & 5.000 & 00 & 00 & 00 & $00^{\mathrm{a}}$ \\
\hline & ET 24h & 5.000 & 03 & 03 & 21 & $27^{\mathrm{b}}$ \\
\hline & ET $48 \mathrm{~h}$ & 5.000 & 06 & 04 & 19 & $29^{\mathrm{b}}$ \\
\hline \multirow{3}{*}{$' 0.04 \mathrm{mg} / \mathrm{mL}$} & $\mathrm{C}$ & 5.000 & 00 & 00 & 00 & $00^{\mathrm{a}}$ \\
\hline & ET $24 \mathrm{~h}$ & 5.000 & 01 & 02 & 20 & $23^{\mathrm{b}}$ \\
\hline & ET $48 \mathrm{~h}$ & 5.000 & 04 & 03 & 21 & $28^{\mathrm{b}}$ \\
\hline \multirow{3}{*}{$0.06 \mathrm{mg} / \mathrm{mL}$} & $\mathrm{C}$ & 5.000 & 0 & 00 & 00 & $00^{\mathrm{a}}$ \\
\hline & ET 24h & 5.000 & 04 & 05 & 13 & $22^{\mathrm{b}}$ \\
\hline & ET $48 \mathrm{~h}$ & 5.000 & 09 & 08 & 14 & $31^{\mathrm{b}}$ \\
\hline \multirow{3}{*}{$0.08 \mathrm{~g} / \mathrm{mL}$} & $\mathrm{C}$ & 5.000 & 00 & 00 & 00 & $00^{\mathrm{a}}$ \\
\hline & ET 24h & 5.000 & 03 & 02 & 20 & $25^{\mathrm{b}}$ \\
\hline & ET 48h & 5.000 & 03 & 03 & 26 & $32^{\mathrm{b}, \mathrm{c}}$ \\
\hline
\end{tabular}

$\mathrm{C}$ - Control; ET - Exposure time, h - hour, d - day.

Means followed by the same letter do not differ significantly at the level of $5 \%$ by the $\chi^{2}$ test.

The cytotoxicity results obtained here corroborate those observed by Barros et al. (2006), who evaluated the bone marrow of rats provided with alcoholic extracts of stonebreaker leaves at a dose of $300 \mathrm{mg} / \mathrm{ml}$ via gavagem and chronic treatment, and found that this plant decreased the cell division rate of marrow cells of these animals, thus being cytotoxic. However, Asare et al. (2012) evaluated the action of alcoholic extracts of $P$. niruri at doses of 30 and $300 \mathrm{mg} / \mathrm{ml}$ on peripheral blood of white mice for ninety days, and found that the extracts were not cytotoxic nor mutagenic in these animals. There are no other studies in the scientific literature that evaluated cytotoxicity and mutagenicity of extracts of $P$. niruri in the test systems with normal cells, i.e those without and previous treatment with clastogenic drugs or with a cell disorder.

Thus, taking into account the results obtained in this present work where the aqueous extracts of P. niruri had antiproliferative and mutagenic action, 
the few studies done to date on the toxic effects of this plant at the cellular level, recognizing that common sense often considers medicinal plants free from adverse reactions to the body often leading to their indiscriminate use, and that the P. niruri plant is easily found in medicinal plant nurseries, herbalists, natural food stores and farmers markets, it is highly relevant to carry out work similar to this one with $A$. сеpa, with other test-systems, exposure times and different treatments to thereby establish, with propriety, what the ideal and safe concentrations are for the use of this plant.

\section{RESUMO}

Este estudo teve por objetivo avaliar a ação de extratos aquosos das folhas secas de Phyllanthus niruri L. (popular quebra-pedras) sobre as células meristemáticas de raízes de Allium cepa L. em quatro concentrações, 0,02 (concentração usual), 0,04, 0,06 e 0,08mg/mL, nos tempos de exposição de 24 e 48 horas. Para cada concentração utilizou-se um grupo de cinco bulbos de cebolas, que primeiramente foram enraizados em água destilada, e em seguida transferidos para as suas respectivas concentrações. As radículas foram coletadas e fixadas em ácido acético (3:1) por 24 horas. As lâminas foram preparadas pela técnica de esmagamento e coradas com orceína acética a $2 \%$. Analisaram-se células em todo ciclo celular, totalizando 5.000 para cada controle e tempo de exposição. Os índices mitóticos calculados foram submetidos à análise estatística do Qui-quadrado $(\mathrm{p}<0,05)$. A partir dos resultados obtidos observou-se que as quatro concentrações testadas, tiveram efeito antiproliferativo significativo sobre o ciclo celular deste sistema-teste. Também se verificou a presença de aberrações celulares como metáfases colchicínicas, pontes anáfásicas e telofásicas, e micronúcleos nos dois tempos de exposição avaliados de todas as concentrações. Portanto, nas condições analisadas, as concentrações de extratos aquosos de folhas secas de P. niruri mostraram-se citotóxicas e genotóxicas.

Palavras-chave: planta medicinal, quebra-pedras, divisão celular, aberrações celulares, Allium cepa.

\section{REFERENCES}

Abdulla ma, Ahmed KAA, Al-BayATy FH AND Masood Y. 2010. Gastroprotective effect of Phyllanthus niruri leaf extract against ethanol-induced gastric mucosal injury in rats. J Pharm Pharmacol 4: 226-230.

Álvarez Al, DiñEIro Y, Del Barrio G, Picinelli A, SuÁrez B AND VALDÉS S. 2009. Bioactivity-guided separation of anti HSV-2 and antioxidant metabolites from the plant Phyllanthus orbicularis. Planta Med 75: 990-991.

Asare GA, Bugyei K, Sittie A, Yahaya ES, Gyan B, Adjei S, AdDo P, WiREDU EK, ADJEI DN AND NyARKo AK. 2012. Genotoxicity, cytotoxicity and toxicological evaluation of whole plant extracts of the medicinal plant Phyllanthus niruri (Phyllanthaceae). Genet Mol 11: 100-111. doi: 10.4238/2012.January.13.3.

AYRES M. 2007. BioEstat 5.0: Aplicações estatísticas nas áreas das ciências biológicas e médicas. Belém: Sociedade Civil Mamirauá, Brasília, CNPq.

Bagatini MD, Silva ACF And Tedesco SB. 2007. Uso do sistema-teste Allium cepa como bioindicador de genotoxicidade de infusões de plantas medicinais. Revista Bras Farmacogn 18: 509-516.

BARros ME, LIMA R, MERCURI LP, MATOS JR, SCHOR N AND BoIM MA. 2006. Effect of Extract of Phyllanthus niruri on crystal deposition in experimental urolithiasis. Urol Res 34: 351-357.

CARITÁ R AND MARIN-MORALES MA. 2008. Induction of chromosome aberrations in the Allium cepa test system caused by the exposure of seeds to industrial effluents contaminated with azo dyes. Chemosphere 72: 722-725.

CIMPLAMT - 2012. Boletim informativo do Centro de Informações sobre Medicamentos a base de Plantas medicinais e Tóxicas. Boletim Informativo. São João Del Rei: Universidade Federal de São João Del Rei.

DEVI V, SHANBHAG TV, BAIRY KL AND SHENOY S. 2005. Effect of Phyllanthus niruri on wound healing in rats. Indian J Physiol Pharmacol 49: 487-490.

FACHINETTO JM, BAGATINI MD, DURIGON ACFS AND TEDESCO SB. 2007. Efeito anti-proliferativo das infusões de Achyrocline satureioides DC (Asteraceae) sobre o ciclo de celular de Allium cepa. Revista Bras Farmacogn 17: 49-54.

FACHINETto JM AND Tedesco SB. 2009. Atividade antiproliferativa e mutagênica dos extratos aquosos de Baccharis trimera (Less.) A. P. de Candolle e Baccharis articulata (Lam.) Pers. (Asteraceae) sobre o sistema teste de Allium cepa. Rev Bras P1 Med 11: 360-367.

FiskesJo G. 1994. Allium Test II: Assessment of a chemicals genotoxic potential by recording aberration in root tips of Allium cepa L. Environ Toxicol 9: 235-241.

Frescura VD, Laughinghouse IV AND Tedesco SB. 2012. Antiproliferative effect of the tree and medicinal species Luehea divaricata on the Allium Cepa cell cycle. Caryologia 65: 27-33.

GRANT WF. 1999. Chromosome aberration assays in Allium. Mut Res 99: 273-291. 
GuerRA M AND SouzA MJ. 2002. Como observar os cromossomos: um guia de técnicas em citogenética vegetal, animal e humana. Ribeirão Preto: FUNPEC.

Herrero O, Perez JMM AND Fernández PF. 2012. Toxicological evaluation of three contaminant of emerging concern by use of Allium cepa test. Mut Res 743: 24-34.

IGANCI JRV, BROBOWSKI G, HEIDEN GVC, STEIN L AND ROCHA BHG. 2006. Efeito do extrato aquoso de diferentes espécies de boldo sobre a germinação índice mitótico de Allium cepa $\mathrm{L}$. Arq Inst Biol 73: 79-82.

LeME DM AND Marin-Morales MA. 2008. Chromosome aberration and micronucleus frequencies in Allium cepa cells exposed to petroleum polluted water - a case study. Mut Res 650: 80-86.

Matsumoto ST, Mantovani MS, Malagutti Mia, Dias AL, FonSECA IC AND MARIN-MORALES MA. 2006. Genotoxicity and mutagenicity of water contamined with tannery, as evaluated by the micronucleus test and comet assay using the fish Oreochromis niloticus and chromosome aberration in onion root-tips. Genet Mol Biol 29: 148-158.
MEYer L, QuAdros KE AND ZENI ALLB. 2011. Etnobotânica na comunidade de Santa Bárbaro Ascurra, Santa Catarina, Brasil. Rev Bras Bioc 10: 258-266.

Moreira J, KLeIN-JúnIOR LC, Cechinel Filho V AND DE CAMPOS BUZZI F. 2013. Anti-hyperalgesic activity of corilagin, a tannin isolated from Phyllanthus niruri L. (Euphorbiaceae). J Ethnopharmacol 146: 318-23. doi: 10.1016/j.jep.2012.12.052.

MuRUGAIYAH V AND CHAN KL. 2009. Mechanisms of antihyperuricemic effect of Phyllanthus niruri and its lignan constituents. J Ethnopharmacol 124: 233-239.

NASCIMENTO-BARRos FR AND AlbUQUERQUE IL. 2012. Substâncias e medicamentos abortivos utilizados por adolescentes em unidade secundária de saúde. RBPS 18: 177-184.

SABINI MC, CARIDDI LN, ESCOBARA FM, BACHETTI RA, Sutil SB, Contigiani MS, ZANON SM AND SABINI LI. 2011. Evaluation of cytogenotoxic effects of cold aqueous extract from Achyrocline satureioides by Allium cepa L test. Nat Prod Commun 6: 995-998. 